\title{
Yearbook of Morphology
}

\author{
Editors: Geert Booij \\ Jaap van Marle \\ Consulting Editors: Stephen Anderson (Yale) \\ Mark Aronoff (Stony Brook, N.Y.) \\ Laurie Bauer (Wellington) \\ Mark Baker (Montreal) \\ Rudie Botha (Stellenbosch) \\ Joan Bybee (Albuquerque, N.M.) \\ Andrew Carstairs-McCarthy (Christchurch) \\ Wolfgang Dressler (Wien) \\ Jack Hoeksema (Groningen) \\ Rochelle Lieber (Durham, N.H.) \\ Peter Matthews (Cambridge, U.K.) \\ Franz Rainer (Wien) \\ Sergio Scalise (Bologna) \\ Henk Schultink (Utrecht) \\ Arnold Zwicky (Columbus, Ohio/Stanford) \\ Editorial address: Editors, Yearbook of Morphology \\ Vakgroep Taalkunde, Vrije Universiteit \\ De Boelelaan 1105 \\ 1081 HV Amsterdam, The Netherlands \\ e-mail: booij@aap.let.vu.nl
}




\title{
YEARBOOK OF MORPHOLOGY 1996
}

\author{
Edited by \\ GEERT BOOIJ \\ General Linguistics, Free University, \\ Amsterdam, The Netherlands \\ and \\ JAAP VAN MARLE \\ Director, \\ P.J. Meertens Institute, \\ Amsterdam, The Netherlands
}


A C.I.P. Catalogue record for this book is available from the Library of Congress

Published by Kluwer Academic Publishers, P.O. Box 17, 3300 AA Dordrecht, The Netherlands.

Sold and distributed in the U.S.A. and Canada by Kluwer Academic Publishers,

101 Philip Drive, Norwell, MA 02061, U.S.A.

In all other countries, sold and distributed

by Kluwer Academic Publishers Group,

P.O. Box 322, 3300 AH Dordrecht, The Netherlands.

Printed on acid-free paper

All Rights Reserved

C) 1997 Kluwer Academic Publishers

No part of the material protected by this copyright notice may be reproduced or utilized in any form or by any means, electronic or mechanical, including photocopying, recording or by any information storage and retrieval system, without written permission from the copyright owner.

Printed in the Netherlands 


\section{Table of Contents}

\section{Theme: Morphology and Psycholinguistics}

A selection of papers from the workshop on 'Morphology: why, how, when, when not, why not?' held at the Max Planck Institute for Psycholinguistics, Nijmegen, June 1995

Guest editors: Harald Baayen and Robert Schreuder

HARALD BAAYEN AND ROBERT SCHREUDER /

Morphology: why, how, when, when not, and why not? 1

FRANK ANSHEN AND MARK ARONOFF/Morphology in real time 9

HARALD BAAYEN, CRISTINA BURANI AND ROBERT SCHREUDER /

Effects of semantic markedness in the processing of regular nominal singulars and plurals in Italian

GEERT BOOIJ / Autonomous morphology and paradigmatic relations

CRISTINA BURANI, FRANCESCA M. DOVETTO, ANNA M. THORNTON

AND ALESSANDRO LAUDANNA / Accessing and naming suffixed pseudo-words

HARALD CLAHSEN / The representation of participles in the German mental lexicon: Evidence for the dual-mechanism model

MICHAEL GASSER / Transfer in a connectionist model of the acquisition of morphology

WILLIAM MARSLEN-WILSON, XIAOLIN ZHOU AND MIKE FORD /

Morphology, modality, and lexical architecture

ARDI ROELOFS / Morpheme frequency in speech production:

Testing WEAVER

\section{Other Articles}

KERSTI BÖRJARS, NIGEL VINCENT AND CAROL CHAPMAN /

Paradigms, periphrases and pronominal inflection:

a feature-based account

LOUISA SADLER, ANDREW SPENCER AND MARINA ZARETSKAYA /

A morphomic account of a syncretism in Russian deverbal

nominalizations

GREGORY T. STUMP / Template morphology and inflectional morphology 


\section{Short Notice}

LAURIE BAUER / Derivational paradigms

\section{Book Notices}

GEERT BOOIJ / Wolfgang U. Dressler and Cristina Burani (eds.),

Crossdisciplinary Approaches to Morphology

MARTIN HASPELMATH / Laura A. Janda, Back from the brink:

analogical extension 


\title{
Autonomous morphology and paradigmatic relations
}

\author{
GEERT BOOIJ
}

\section{INTRODUCTION ${ }^{1}$}

In a number of recent studies attention has been drawn to the fact that the morphology of a language does not always exhibit a simple relation between form and meaning. That is, the formal side of morphology has a certain autonomy. The title of Aronoff's recent book, Morphology by Itself (Aronoff 1994) nicely expresses this idea of the autonomy of morphological form. For instance, the form-meaning relations in inflection may be mediated by inflectional classes (declinational classes for nouns and adjectives, and conjugational classes for verbs). As Aronoff (1994) pointed out, the existence of such classes results in one-to-many relations between morphosyntactic properties of lexemes and their phonological forms.

Another important case of 'morphology by itself', i.e. of autonomous morphology is the phenomenon of stem allomorphy. A stem is "that sound form to which a given affix is attached, or upon which a given non-affixal realizational rule operates" (Aronoff 1994: 39). For instance, the Latin verbal paradigm exhibits three stems, a present stem for present and past tense, a perfect stem, and a third stem for, among others, the formation of past partciples. Thus, the verb armare 'to arm', with the thematic vowel /a/ of the first conjugation, has three stems, arm- $a$ (present stem), $a r m a-v$ (perfect stem, as in arm- $a-v-i$ 'I have armed'), and arma- $t$ (third stem, as in arm- $a-t-u s$ 'armed, past participle'). Similarly, Vogel (1994) argued that the verbal morphology of Italian also requires three stem forms. This kind of stem allomorphy cannot be captured by rules of phonology. However, it is often possible to formulate morphological rules that generate such 'stem paradigms'.

Stem allomorphy is not restricted to the Indo-European language family, but can also be found in, for instance, the Daghestan language Lezgian (Haspelmath 1993), the Austronesian language Muna (Van den Berg 1989), and the Nilo-Saharan language Turkana (Dimmendaal 1983), to name just a few.

The idea that more than one stem is needed for a lexeme for a proper account of morphological operations, both inflection and derivation, is not new, as Aronoff himself points out very clearly. What he wants to stress is that when a lexeme has more than one stem, this is not necessarily a matter of listing the different stems (as was suggested in Lieber 1981), but that the form of a stem may also be determinable by rule, as is often the case in Latin: once we know the first stem, with its theme vowel, the second and third stem can be derived by rule, by adding $v$ and $t$ respectively. Crucially, however, these elements have no particular meaning, they are only there for the sake of proper morphological form. Therefore, Matthews (1972), following Hockett, refers to such elements as 'empty morphs'. 
This implies that morphology cannot be reduced to 'the syntax of morphemes': we need a level in the grammar at which the form of words is computed by means of rules which are purely morphological, i.e. they only pertain to the forms of words, not to their meanings. The same conclusion has already been arrived at by Matthews (1972: 107): “... the structure of the word form must be supplied by statements of a wholly morphological nature”.

In this paper, I want to discuss stem allomorphy in more detail, mainly based on data from Dutch. First, I will show that stem allomorphy is not restricted to inflection, but also pervasive in derivation. Second, and more importantly, I will argue that in many cases the stem allomorph that has to be used in word formation is determined on the basis of paradigmatic relations between words. Thus, it is shown that an exclusively syntagmatically oriented morphology cannot capture certain generalizations with respect to the form of morphologically complex words.

\section{STEM ALLOMORPHY IN DERIVATIONAL MORPHOLOGY}

Extensive stem allomorphy in derivational morphology can be found in the nonnative part of the lexicon of Dutch. Many non-native lexemes appear to have two stems: one that is the proper one for non-native suffixation, and another one (the default one) in all other cases, for instance when the word is used in isolation. The following examples illustrate this phenomenon:

(1) word apost[ə]l 'apostle'

drama 'drama'

functie 'function'

Calvijn 'Calvin'

cursus 'course'

gymnasium 'grammar school'

horizon 'id.' orkest 'orchestra' dramat-

non-word stem apostol-

function-

calvin-

curs-

gymnasi-

horizontorkestr- non-native derivations apostol-isch 'apostolic', apostol-aat 'apostolate', apostol-air 'apostolic' dramat-isch 'dramatic', dramat-iek 'dramatics', dramat-urg 'dramatist' function-eel 'functional', function-eer 'to function', function-aris 'functionary' calvin-isme 'calvinism', calvin-ist 'id.'

curs-ist 'student', curs-orisch 'in a course'

gymnasi-aal 'of a grammar school'

gymnasi-ast 'grammar school pupil'

horizont-aal 'horizontal' orkestr-eer 'to orchestrate', orkestr-atie 'orchestration', orkestr-ion 'orchestrion' 
Clearly, this kind of allomorphy is not a matter of phonology, but of 'pure' morphology. For instance, there is no rule of Dutch phonology that could account for the deletion of the word-final / $\mathrm{t} /$ of the stem horizont- 'horizon', nor a rule of vowel reduction that can obligatorily reduce the last vowel of apostol-into a schwa.

The analysis of such formal variation that I would like to suggest for the cases in (1) is indeed an analysis in terms of stem allomorphy. For instance, the occurrence of the string -oneel besides -eel is not to be interpreted as a case of suffix allomorphy, but of stem allomorphy. In this way, we correctly predict that the 'intermorph' -onrecurs in every derivation from a word such as functie, as the relevant examples in (1) show. This also implies that a sequence such as on does not have the status of a suffix, contrary to what Beard (1993: 724) suggested.

In the cases at hand, there is no rule that can derive one stem allomorph from the other. Both stem allomorphs have to be listed in the lexicon; one is subcategorized for non-native suffixation (apostol-, dramat-, function-, etc.), and the other one is the default allomorph that is to be used in native suffixation, in prefixation, when the word is used in isolation, and in compounding.

Stem allomorphy also plays an important role in the native morphology of Dutch. Quite a number of words ending in schwa have a schwa-less allomorph (data mainly from Van Marle (1982):

(2) Drente 'id.' Suriname 'Surinam'

Zwolle 'id.' Veluwe 'id.'

aarde 'earth'

karbonade 'cutlet' machine 'engine' weduwe 'widow' vrede 'peace' schande 'shame'

\author{
Drent-s 'of Drente' \\ Surinaam-s 'of Surinam' \\ Zwol-s 'of Zwolle' \\ Veluw-s 'of Veluwe', Veluw-naar 'inhabitant of \\ Veluwe' \\ aard-s 'earthly', aard-olie 'petroleum', aard-noot \\ 'peanut' \\ karbonaad-je 'cutlet, dim.' \\ machien-tje 'dim.' \\ weduw-schap 'widowhood' \\ vreed-zaam 'peaceful' \\ schand-vlek 'disgrace', schand-paal 'pillory'
}

The disappearance of the stem-final schwa cannot be explained by a synchronic rule of schwa-deletion of Dutch. Dutch only has an automatic phonological rule of prevocalic schwa-deletion (Booij 1995a: 68). Also, there is no rule of stem allomorphy which states that every stem ending in schwa has a schwa-less allomorph (compare bode /boda/ 'messenger' - bodetje / *boodje, or seconde /səkonda/ 'second' / secondetje / *secondje. Therefore, both allomorphs have to be listed in the lexicon. The schwa-less allomorph is subcategorized for derivation and composition, the other one is the default allomorph. Interestingly, the default allomorph with final schwa has to be used in inflection. For instance, the genitive form of Drente is Drente's, not Drents. This shows that inflection and derivation indeed have to be distinguished as different subcomponents of the grammar. ${ }^{3}$ As Van Marle (1982: 
333) pointed out, there is also a number of words, both allomorphs of which occur as independent words; both forms have to be listed in the lexicon:

(3) einde/eind 'end', keuze/keus 'choice', klasse/klas 'class', wijze/wijs 'manner'

There is also a number of toponyms in -en with an allomorph without -en, to be used in derivational suffixation:

(4) Groningen 'id.'

Groning-er (inhabitant name), Groning-s (adj.)

Vlissingen 'Flushing'

Nijmegen 'id.'

Vlissing-er (inhabitant name), Vlissing-s (adj.)

Nijmeeg-s (adj.)

Again, both allomorphs have to be listed since there are other toponyms in -en without a shortened allomorph, for instance Haren 'id.' with the adjective Haren-er.

A final example of native stem allomorphy in Dutch is shown in the following compounds and suffixed words:

(5) noorden 'north'

noorder-licht 'northern lights', noorder-ling 'northerner'

westen 'west'

wester-kim 'western horizon', Wester-kwartier

'Western quarter'

oosten 'east'

Ooster-hout 'Eastwood', ooster-ling 'easterner'

zuiden 'south'

Zuider-zee 'Southern sea', Zuider-land

'Southern country'

In these cases, each noun in -en has an allomorph in -er.

In sum, stem allomorphy is a widespread phenomenon in Dutch word formation.

\section{PARADIGMATICALLY DETERMINED ALLOMORPHY}

\subsection{Noun allomorphy}

Dutch has fifteen nouns with a stem allomorph ending in -er that has to be used in inflection, and is optionally used in compounding and derivation:

(6)

\begin{tabular}{|c|c|c|}
\hline kind 'child' & $\begin{array}{l}\text { plural } \\
\text { kinder-en }\end{array}$ & $\begin{array}{l}\text { compounding/derivation: } \\
\text { kinder-wagen 'pram', kinder-achtig } \\
\text { 'childish' }\end{array}$ \\
\hline kalf 'calf' & kalver-en & kalver-melk 'calf's milk' \\
\hline rund 'cow' & runder-en & $\begin{array}{l}\text { runder-leer 'cow's leather', runder-lapje } \\
\text { 'beefsteak' }\end{array}$ \\
\hline 'egg' & eier-en & eier-doos 'egg box', eier-dooier 'egg yolk' \\
\hline
\end{tabular}


In traditional grammars of Dutch, the sequence - eren is often interpreted as a third plural ending, besides the suffixes $-s$ and $-e n$. However, the examples given above clearly show that the occurrence of $-e r$ is not restricted to plural forms. Therefore, we have to interpret the forms in -er as stem allomorphs. Nevertheless, we want to express that only those nouns have such allomorphs that have a plural form in -eren. So, as proposed by Van den Toorn (1982: 27) and Van Marle (1985: 17-18), the occurrence of the -er-allomorph is paradigmatically determined, i.e. by the existence of a morphologically related form with -er:

(7) Nouns with a plural form in -eren have a stem allomorph in -er.

It is not predictable which allomorph should be used. For instance, we find rundvlees 'beef' besides runder-lapje 'beef steak'.

A remarkable complication in the selection of the allomorph in -er is that the stem kinder 'child' can be used in the plural diminutive form kind-er-tje-s 'little children', but not in the singular form: *kind-er-tje is impossible; instead, one has to use kindje 'little child', which also has the plural form kindjes. That is, it seems that the selection of the correct allomorph is not determined locally, by the adjacent diminutive suffix $-t j e$, but by the plural suffix $-s$. This suggests a paradigmatic analysis of plural diminutives. Just as traan-tje-s 'little tears' can be seen as formed by replacement of the plural suffix -en of tran-en 'tears' with the suffix sequence -tje-s, so kindertjes can be interpreted as being derived from kinder-en 'children' by the same kind of suffix replacement.

In Dutch, stem allomorphy of nouns also occurs at a large scale in the domain of compounding. Traditionally, we speak of two linking phonemes or linking morphemes, / / / and /s/ that link the constituents of compounds. However, phonologically these linking phonemes belong to the first constituent, as is clear from the fact they surface under gapping. The rule is that one of two identical prosodic words can be deleted (Booij 1985):

(8) hond[ə]- en katt[ə]brood 'dog food and cat food' pruim[ə]- of appelboom 'plum tree or apple tree' zons- en maansverduistering 'sun eclipse and moon eclipse'

Moreover, the occurrence of such a linking element only depends on the first constituent. Therefore, the term 'linking morpheme' is not correct; rather, we should interpret this phenomenon as stem allomorphy in the first part of the compound.

As far as the occurrence of the allomorph in schwa is concerned, the following generalization can be made (Van Marle 1985, De Haas \& Trommelen 1993: 404ff):

(9) Only nouns with a plural in -en can have an allomorph in - $e$ in the nonhead-position of a compound.

(Recall that Dutch has two plural suffixes, $-s$ and -en.) So, a noun such as schaap 'sheep' has three allomorphs, schaap, schaaps and schape: 
(10) schaap-herder 'shepherd', schaaps-kooi 'sheep-fold', schape-vlees 'mutton'

Nouns with the plural suffix $-s$, on the other hand, can only have an allomorph in $-s$, never one in -en. For instance, the word portier 'porter' has the plural form portier-s. Therefore, we do find a compound such as portierswoning 'porter's lodge', but a compound *portierewoning is ill formed. The choice between one of these allomorphs is mainly a matter of convention, and eurhythmic factors may also play a role (cf. Van den Toorn 1982). For nouns that select the plural suffix $-s$ (which therefore do not have an allomorph in schwa), the allomorph in $s$ is only possible for [+animate] nouns: varkens-s-vlees 'lit. pig's meat, pork' versus kamerorkest I *kamer-s-orkest 'chamber orchestra'.

In short, the relevant generalization can only be made in terms of paradigmatic relations between (forms of) words. The allomorph ending in schwa need not be listed but can be computed on the basis of the following formula:

(11) Noun allomorph with final schwa in non-head position of compounds = plural form minus $/ \mathrm{n} /$

This formula has the additional advantage that it predicts that, if the stem of a plural noun differs from that of the singular noun, this allomorphy will also recur in the stem allomorph with final schwa that is used in compounding. In particular, Dutch has a number of nouns that exhibit vowel lengthening in plural forms (Booij 1995a: 87):

(12)

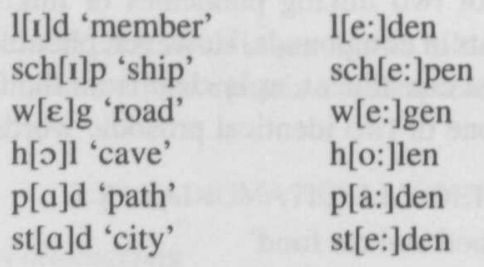

These 'long' stem allomorphs also occur in word formation when there is no stemfinal schwa:

$$
\begin{aligned}
& \text { singular plural } \\
& \text { sch[I]p 'ship' sch[e:]pen 'ships' sch[e:]psbouw 'ship-building', } \\
& \text { sch[e:]pje 'ship, dim.', insch[e:]pen 'to } \\
& \text { embark' versus Sch[ı]phol 'lit. ship } \\
& \text { harbour', sch[I]pper 'skipper' } \\
& \text { p[a]d 'path' p[a:]den 'paths' p[a:]dje 'path, dim.' versus } \\
& \mathrm{p}[\mathrm{a}] \mathrm{dvinder} \text { 'boy scout' }
\end{aligned}
$$

Given the formula in (11), we correctly predict that we find a compound such as stedebouw 'lit. town building', but that an allomorph stadde, as in *staddebouw is 
impossible. Similarly, we find both lidmaat 'member' and ledematen 'limbs', but liddemaat is ill formed. ${ }^{4} \mathrm{~A}$ similar reasoning holds for schwa-less allomorphs such as scheep and paad mentioned in (12): such long stem allomorphs only occur if they also occur in the plural forms, and so these allomorphs should be computed in a similar way, according to the formula 'allomorph in schwa = plural form minus -en'.

One might argue that reference to the plural form of nouns in computing this type of stem allomorphy can be avoided by imposing the same (prosodic) conditions that hold for the plural suffix /-an/ on the occurrence of the linking phoneme (the rule is that -en occurs after a stem ending in a stressed syllable, and $-s$ after an unstressed syllable, with the effect that plural nouns end in a trochee, cf. Booij \& Van Santen 1995, Booij 1996a). In such an analysis, there would be no need to refer to another paradigmatic form of the word. However, we already saw that irregularities of plural forms recur in the stem allomorphs. This would not follow from an analysis in which the occurrence of the schwa is determined by the same prosodic conditions as the plural suffix -en without positing any formal relation between the schwa-final allomorph and the plural form. Other crucial evidence that we have to refer to the plural form is constituted by the following facts. A number of monosyllabic nouns are exceptions in that they select $-s$ instead of the regular -en, and this correlates exactly with the impossibility of using the schwa as stem extension for such nouns:

$\begin{array}{ll}\begin{array}{ll}\text { singular } \\ \text { tram 'id.' }\end{array} & \begin{array}{l}\text { plural } \\ \text { trams, *trammen } \\ \text { flat }\end{array} \\ \begin{array}{ll}\text { flats, *flatten } \\ \text { 'apartment' }\end{array} \\ \text { station 'id.' } & \begin{array}{l}\text { stations, } \\ \text { *stationnen }\end{array}\end{array}$

\section{compound}

tramdeur, *trammedeur 'tram door'

flatbouw, *flattebouw 'building of

apartments'

stationsweg, *stationneweg 'station road'

Inversely, there are nouns that exceptionally take -en instead of $-s$, and these nouns do have the stem allomorph with the final schwa (spelled as $e$ or $e n$ in compounds):

(15)

$\begin{array}{ll}\begin{array}{ll}\text { singular } \\ \text { engel 'angel' }\end{array} & \begin{array}{l}\text { plural } \\ \text { engelen, *engels }\end{array} \\ \text { christen } & \text { christenen, } \\ \text { 'Christian' } & \text { *christens } \\ \text { scholier } & \text { scholier-en', } \\ \text { 'student' } & \text { *scholier-s }\end{array}$

\section{compound}

engelenhaar 'angel's hair'

christenezielen 'exclamation'

scholierenkaart 'student's card'

The other type of plural noun, that in $-s$, also plays a role in the allomorphy of the non-head constituent of compounds: when the non-head of the compound is a diminutive, we have to use the plural form of that diminutive as stem allomorph: 
(16)

$\begin{array}{lll}\begin{array}{l}\text { noun } \\ \text { meisje 'girl' }\end{array} & \begin{array}{l}\text { plural } \\ \text { meisje-s }\end{array} & \begin{array}{l}\text { compound } \\ \text { meisje-s-boek 'girl's book' } \\ \text { meisje-s-lijk 'girl's corpse' } \\ \text { meisje-s-achtig 'girlish' } \\ \text { vrouwtje-s-olifant 'female elephant' }\end{array} \\ \begin{array}{l}\text { vrouwtje } \\ \text { 'woman, dim.' } \\ \text { potje 'pot, dim.' } \\ \text { bloemetje } \\ \text { 'flower, dim.' }\end{array} & \begin{array}{l}\text { prouwtje-s } \\ \text { rijtje 'row. dim.' }\end{array} & \begin{array}{l}\text { rij-tje-s } \\ \text { potje-s-latijn 'dog Latin' } \\ \text { bloemetje-s-gordijn 'curtain with } \\ \text { floral pattern' } \\ \text { rijtjes-huis 'terrace house, row house' }\end{array}\end{array}$

Although the form is that of the plural, there is not necessarily a plural meaning involved, as is clear from the examples meisjeslijk, vrouwtjesolifant and rijtjeshuis, in which only one meisje, vrouwtje or rijtje is involved. For example, a rijtjeshuis forms part of only one rijtje 'row'. So we find here another case of a purely formal regularity, a case of 'morphology by itself', in which paradigmatic relations play a crucial role: the stem allomorph of the diminutive in the non-head position of compounds is formally identical to the plural diminutive.

In sum, we can conclude that generalizations with respect to the stem allomorphy exhibited by the first (nominal) members of compounds can only be made in terms of paradigmatic relations between words.

\subsection{Verbal allomorphy}

Apart from the verb zijn 'to be', there are five verbs in Dutch that do not have the normal infinitive which consists of the verbal stem followed by -en /on/. Instead, they have infinitives consisting of the stem $+-n$ :

(17) doe-n /du-n/ 'to do', gaa-n /ra-n/ 'to go', slaa-n /sla-n/ 'to hit', staa-n /sta-n/ 'to stand', zie-n /zi-n/ 'to see'

The stems themselves occur as concrete words, as the 1st pers. sg. pres. tense form:

(18) doe /du/, ga /ra/, sla /sla/, sta /sta/, zie /zi/

Nevertheless, it is the form that is identical to the infinitival form that functions as the stem form for further deverbal derivation:

(19) doen-er 'doer', be-doen-ing 'behaviour', on-doen-lijk 'impossible' be-gaan-baar 'passable', uit-gaan-der 'out-goer', gaan-derij 'gallery' zien-er 'prophet', aan-zien-lijk 'considerable', on-zien-lijk 'invisible', voor-zien-ing 'provision', voor-zien-ig 'providential'

This contrasts with verbs with an infinitive in -en: for such verbs the stem form is used as the base for derivational morphology. For instance, the subject noun for the 
verb werken 'to work' is werk-er, not *werken-er. Although for the five verbs mentioned it is a form identical to the infinitival form that functions as the stem for deverbal derivation, there is no infinitival property such as nouniness implied. Note also that the suffixes involved in (19) are deverbal ones, whereas in Dutch word formation infinitives behave as nouns with respect to derivational morphology (Booij 1989), as illustrated by the words weten-schap 'science' and zeggen-schap 'authority', with the denominal suffix -schap. In sum, what we find here is the stem allomorphy rule that for verbs with an infinitive in $-n$, the form of the infinitive also functions as the stem to which derivational rules apply.

The persistence and pervasiveness of the allomorphy of these five verbs may have to do with their high frequency, which is an important factor in preserving allomorphy.

A related observation about Dutch is that the form of the present participle is always that of the infinitive, plus /d/. For instance, the present participle of the verb werk 'to work', with the infinitival form werk-en is werkend 'working'. Of course, we could say that the infinitive is formed by suffixing the verbal stem with -en, and the present participle by suffixing the verbal stem with -end. That is, the similarity between these two forms of the verbal paradigm would be completely coincidental. However, by claiming that the present participle is formed by adding $-d$ to a stem that has a form identical to that of the infinitive, we correctly predict that the present participle of those verbs that have an exceptional infinitive ending in $-n$ have an exceptional present participle ending in -nd instead of the regular-end:

(20) zijn-d/zeind/ 'being', doen-d/dund/ 'doing', gaan-d/rand/ 'going', slaan-d /sland/ 'hitting', staan-d/stand/ 'standing', zien-d/zind/ 'seeing'

The five verbs with infinitives in $-n$ discussed here exhibit yet another type of paradigmatically determined allomorphy. In many compounds and derived words the form of the corresponding noun functions as verbal stem allomorph, as the following examples show:

\section{(21) verb noun complexwords}

doen daad dad-er 'lit. doer, delinquent'

gaan gang kerk-gang-er 'churchgoer', gang-baar 'current', gang-pad 'aisle', toe-gank-elijk 'accessible'

slaan slag slag-er 'butcher', na-slag-werk 'reference book', slag-boom 'barrier', slag-zin 'slogan'

staan stand stand-plaats 'position', mede-stand-er 'supporter', om-stand-er 'bystander', stand-aard 'standard'

zien zicht zicht-baar 'visible', op-zicht-ig 'showy', op-zicht-er 'overseeer', over-zicht-elijk 'clearly arranged', door-zicht-ig 'transparent' 
In the case of complex words ending in the exclusively deverbal suffix -baar it is clear that the stem, although it has the same form as that of a corresponding noun, does not count as a noun: since a deverbal suffix is attached, it has to be interpreted as an allomorph of the verbal stem. Some of the suffixes involved can also be used denominally, but semantically all these complex words are completely parallel to deverbal complex words, and they are felt by native speakers of Dutch as variants of the verbal stem (cf. Van Haeringen 1962; De Haas \& Trommelen 1993). Note also that parallel words with the 'normal' verbal stem ususally do not exist. For instance, we do not find *kerkgaer or *gabaar besides kerkganger and gangbaar. ${ }^{6}$ So, this is another case of paradigmatically determined allomorphy: the stem allomorph is formally identical to that of the corresponding noun. Note also that that these nouns cannot be derived by a regular word formation rule, i.e. we cannot derive these stem allomorphs by rule, without taking the nouns into account.

A type of morphological rule that is not discussed in Aronoff (1994) is the 'rule of referral', a notion introduced by Zwicky (1985). Such rules can express cases of systematic syncretism. For instance, in Latin plural forms of nouns the dative always has the same form as the ablative. That is, once we know the plural dative form, the plural ablative form is predictable. This is again an example of a formal regularity in which paradigmatic relations play a role.

An interesting example of the kind of regularity that a rule of referral (in the more general sense of a rule that relates forms of an inflectional paradigm) can express is the following observation about Dutch: the infinitive form is also the plural present tense form of verbs. That is, the present tense plural form is predictable once we know the form of the infinitive, and vice versa. This is a relevant generalization, because it also holds for verbs with an irregular infinitive. In particular, the six verbs mentioned above with an irregular infinitive in $-n$ also have a present tense plural form in $-n$ instead of $-e n$. The same applies to the irregular verb komen 'to come' that exhibits vowel change, and to those modal verbs for which the stem for the singular forms differs from that for the plural:

(22)

infinitive
$\mathrm{k}[\mathrm{o}] \mathrm{men}$ 'to come'
kunnen 'can'
mogen 'may'
zullen 'will'

$\begin{array}{ll}\text { 1st pers. } s g . & \text { pl. } \\ \mathrm{k}[\mathrm{o}] \mathrm{m} & \mathrm{k}[\mathrm{o}] \mathrm{men} \\ \mathrm{kan} & \text { kunnen } \\ \text { mag } & \text { mogen } \\ \text { zal } & \text { zullen }\end{array}$

The question may be raised now whether native speakers of Dutch really make this generalization about the verbal paradigm. One might argue that since all verbal forms have the structure stem + ending, the plural form and the infinitive are derived by rule in a syntagmatic way, by adding the ending -en to the stem, at least in the regular cases. In particular, for newly derived verbs it seems a bit odd to claim that one cannot compute the form of the infinitive without determining the plural form, or vice versa. Note also that there is a number of Dutch verbs that only occur in the infinitive, and do not have tense forms (Booij 1989). On the other hand, there is 
evidence that the relation of formal identity between plural form and infinitive does play a role. As Jaap van Marle pointed out to me, children who generalize the stem form of the singular form to the plural form (maggen instead of mogen, cf. 22), also have the infinitive maggen. So we might conclude that verbal forms allow for a dual analysis, a syntagmatic and a paradigmatic one, which are both correct.

\section{TOPONYMIC DERIVATIONS}

Another area in which paradigmatically determined allomorphy plays a considerable role is that of toponymic derivations. Consider the following data concerning inhabitatives and toponymic adjectives in Dutch:

$\begin{array}{lll}\text { (23) } \begin{array}{l}\text { toponym } \\ \text { Provençe }\end{array} & \text { inhabitative } & \text { toponymic adjective } \\ \text { Amerika } & \text { Provençaal } & \text { Provençaal-s } \\ \text { Catalonië } & \text { Amerikaan } & \text { Amerikaan-s } \\ \text { Guatemala } & \text { Catalaan } & \text { Catalaan-s } \\ \text { Chili } & \text { Guatemalteek } & \text { Guatemalteek-s } \\ \text { Madrid } & \text { Chileen } & \text { Chileen-s } \\ \text { Portugal } & \text { Madrileen } & \text { Madrileen-s } \\ \text { Ambon } & \text { Portugees } & \text { Portugees } \\ \text { Rome } & \text { Ambonees } & \text { Ambonees } \\ \text { Palestina } & \text { Romein } & \text { Romein-s } \\ \text { Bretagne } & \text { Palestijn } & \text { Palestijn-s } \\ \text { Azië } & \text { Breton } & \text { Breton-s } \\ \text { Monaco } & \text { Aziaat } & \text { Aziat-isch } \\ \text { Israel } & \text { Monegask } & \text { Monegask-isch } \\ \text { Moskou } & \text { Israeliet } & \text { Israelit-isch } \\ & \text { Moskoviet } & \text { Moskovit-isch }\end{array}$

(Similar patterns in the coining of German toponymic adjectives are observed by Becker (1990: 42)). The most straightforward formal analysis of the toponymic adjectives which are semantically derived from the toponyms is an analysis in which the suffixes $-s$ and $-i s c h$ are attached to a stem allomorph of the toponym which is formally identical to the corresponding inhabitative noun, another case of paradigmatically determined stem allomorphy.

This pattern is not restricted to geographical words, we also find it for other proper names, and the words derived from them:

(24)

$\begin{array}{ll}\text { proper name } & \text { follower } \\ \text { Chomsky } & \text { Chomsky-aan } \\ \text { Schultink } & \text { Schultink-iaan } \\ \text { Reve } & \text { Rev-iaan }\end{array}$

adjective

Chomskyaan-s 'Chomskyan'

Schultinkiaan-s 'Schultinkian'

Reviaan-s 'Revian'

That is, the adjectives involved all belong to the set of relational adjectives. 
Another possible analysis of these data can be found in Smedts $(1973,1974) . \mathrm{He}$ argued that we can assign an inhabitative such as Amerikaan the following structure:

(25) Amerik-aan- $\varnothing$

In this structure, aan is a concatenator, an empty morpheme, that extends the stem before it is affixed. The actual denominal suffix is the zero-morpheme. Such connectors are often assumed in morphological analyses of Slavic languages such as Russian (Shapiro 1966) and Polish (Szymanek 1985). For instance, Polish denominal adjectives exhibit a number of such concatenators:

\begin{tabular}{|c|c|}
\hline $\begin{array}{l}\text { Hitler 'id.' } \\
\text { niebo 'heaven' }\end{array}$ & $\begin{array}{l}\text { Hitler-ow-ski 'Hitler-' } \\
\text { nieb-ian-ski 'heavenly' }\end{array}$ \\
\hline & brat-er-ski 'broeder \\
\hline & krol-ew-ski 'royal' \\
\hline
\end{tabular}

These concatenators (aan, aal etc.), Smedts argued, also show up in the toponymic adjectives. Consequently, it will be possible to analyze the toponymic adjectives as derived from the (extended stem of the) toponyms, without the inhabitatives playing a role. Moreover, as Smedts argued, such a non-paradigmatic analysis correctly predicts that the toponymic adjectives for native toponyms are not 'derived from' the inhabitative, but directly from the toponym:

\section{(27) Amsterdam / Amsterdammer / Amsterdams - *Amsterdammers}

Note, however, that such an analysis does not account for the fact that other irregularities of the inhabitative also recur in the toponymic adjective. For instance, the inhabitative Madril-een has an irregular $/ \mathrm{l} /$ instead of a $/ \mathrm{d} /$, which also shows up in the toponymic adjective. Similarly, the part Moneg in Moneg-ask differs from Monaco, and the part Portug in Portug-ees from Portugal. In addition, there are quite a number of inhabitatives that are simplex nouns from which the toponym is often derived. Yet, in these cases as well the toponymic adjective has the formal structure 'form of inhabitative $+-s /-i s c h$ ':

(28)

toponym
Zeeland 'Sealand'
Gr-Brittannië 'Gr. Br.'
Finland 'id.'
Zwitserland 'Switzerland'
Noorwegen 'Norway'
Hongarije 'Hungary'
Bulgarije 'Bulgaria'
Roemenië 'Rumania'
België 'Belgium'
Rusland 'Russia'

$\begin{array}{ll}\text { inhabitative } & \text { toponymic adjective } \\ \text { Zeeuw } & \text { Zeeuw-s } \\ \text { Brit } & \text { Brit-s } \\ \text { Fin } & \text { Fin-s } \\ \text { Zwitser } & \text { Zwitser-s } \\ \text { Noor } & \text { Noor-s } \\ \text { Hongaar } & \text { Hongaar-s } \\ \text { Bulgaar } & \text { Bulgaar-s } \\ \text { Roemeen } & \text { Roemeen-s } \\ \text { Belg } & \text { Belg-isch } \\ \text { Rus } & \text { Russ-isch }\end{array}$


Therefore, I take it that the derivation of toponymic adjectives is a clear case of paradigmatically determined stem allomorphy.

These stem allomorphs also show up in other cases of non-native suffixation. For instance, in addition to Amerikaans we also find Amerikan-ist 'student of America' and Amerikan-isme 'Americanism'.

Thus, the following generalization can be established for Dutch:

(29) The stem allomorph of non-native toponyms and proper names to be used in derivation is formally identical to the corresponding denominal personal name.

By restricting this allomorphy rule to non-native toponyms, we exclude ill formed toponymic adjectives such as *Amsterdammers instead of the correct Amsterdams. The only cases where this regularity does not hold is when there is another geographical adjective that blocks the formation of the geographical adjective on the basis of the inhabitant name. This is the case for adjectives such as Spaans 'Spanish', Engels 'English', Frans 'French' and Duits 'German'.

A related case of paradigmatic allomorphy is the formation of female inhabitatives. Unlike what we may expect, such nouns are not derived from their neutral counterpart, but from the corresponding toponymic adjective, by adding a suffixal schwa:

(30) inh

Provençaal

Amerikaan

Catalaan

Guatemalteek

Chileen

Madrileen

Portugees

Ambonees

Romein

Palestijn

Breton

Aziaat

Monegask

Israeliet

Moskoviet toponymic adjective

Provençaal-s

Amerikaan-s

Catalaan-s

Guatemalteek-s

Chileen-s

Madrileen-s

Portugees

Ambonees

Romein-s

Palestijn-s

Breton-s

Aziat-isch

Monegask-isch

Israelit-isch

Moskovit-isch female inhabitative

Provençaalse

Amerikaanse

Catalaanse

Guatemalteekse

Chileense

Madrileense

Portugese

Ambonese

Romeinse

Palestijnse

Bretonse

Aziatische

Monegaskische

Israelitische

Moskovitische

This generalization also holds for native female inhabitatives, and for non-native female inhabitatives where the toponymic adjective is not derived form the inhabitative:? 
(31) inhabitative

Amsterdammer

Zeeuw

Spanjaard

Fransman

Duitser adjective

Amsterdam-s

Zeeuw-s

Spaans

Frans

Duits female inhabitative

Amsterdamse

Zeeuwse

Spaanse

Franse

Duitse

In a few cases there are alternative female inhabitatives derived from the neutral counterpart, e.g. Russin and Friezin. Even when such alternatives exist they do not block the formation of female inhabitatives such as Russische and Friese.

In conclusion, the morphological system for the formation of geographical adjectives and female inhabitatives forms a strong case for the role of paradigmatically determined allomorphy.

\section{GENDER AND CONVERSION}

Another area of morphology that shows the possible relevance of paradigmatic relations for regularities in the formal make up of words is that of gender assignment. The role of gender in morphological systems is a typical example of autonomous morphology (Aronoff 1994). Present-day Dutch has two gender classes, neuter and non-neuter. In many cases the gender of a complex noun is determined by one of its constituents; compounds inherit the gender of their (right-hand) head, and in derived words it is the nominalizing prefix or suffix that determines gender. For instance, the deverbal nominalizing prefix ge- and suffix -ing create neuter and nonneuter nouns respectively. However, in a number of cases the gender of the resulting noun cannot be computed in this way. These cases all concern the conversion of complex verbs into nouns.

The first case is that of nouns derived through conversion from prefixed verbs. These nouns are systematically neuter nouns, unlike their counterparts, the nominal conversions of simplex verbs which are non-neuter (Trommelen \& Zonneveld 1986, Don 1993); de is the def. sg. article for non-neuter nouns, and het is the neuter def. sg. article:

\begin{tabular}{|c|c|c|c|}
\hline simplex verb & noun & prefixed verb & noun \\
\hline raad 'to advise' & de raad 'advice' & be-raad & het beraad \\
\hline & $\begin{array}{l}\text { ver-raad } \\
\text { 'to betray' }\end{array}$ & $\begin{array}{l}\text { 'to deliberate' } \\
\text { het verraad } \\
\text { 'betrayal' }\end{array}$ & 'deliberation' \\
\hline roep 'to call' & de roep 'call' & be-roep 'to call' & $\begin{array}{l}\text { het beroep } \\
\text { 'profession' }\end{array}$ \\
\hline zet 'to put' & de zet 'the push' & $\begin{array}{l}\text { ont-zet } \\
\text { 'to relieve' }\end{array}$ & $\begin{array}{l}\text { het ontzet } \\
\text { 'relief' }\end{array}$ \\
\hline
\end{tabular}


The interesting aspect of the converted prefixed nouns is that they do not contain a specific morpheme to which the neuter gender can be assigned. Gender is only predictable by making use of information about the corresponding verb.

Conversion as a word formation process can be readily interpreted in terms of paradigmatic relations: a systematic difference in form (namely word class) correlates with a systematic difference in meaning. In such an interpretation we are not forced to assume zero-morphemes (zero-suffixes or zero-prefixes). Therefore, if the gender of converted nouns is determined by the nature of the corresponding verb, it is a typical case of a paradigmatically determined formal property of a class of words.

Interestingly, Don (1993) attempted to give a syntagmatic account of the gender regularities discussed here by assuming that the nouns are derived from these prefixed verbs by means of the nominalizing prefix ge- which is deleted before the unstressed prefixes be-, ont-, and ver-. Recall that this prefix creates neuter nouns. Also, the prefix ge- does not surface before unstressed prefixes in Dutch past participles. For instance, the past participle of beplanten 'to plant' is beplant, not *gebeplant. Nevertheless, it is impossible to assume a general rule of ge-deletion before unstressed prefixes since the nominalizing prefix ge- does occur before unstressed prefixes, as in the following examples (Schultink 1995: 117, Booij 1995b: 299):

(33) verb

be-lazer 'to cheat' ver-geet 'to forget' ont-leed 'to analyse' be-ge-leid 'to coach' be-weeg 'to move' ver-sier 'to decorate'

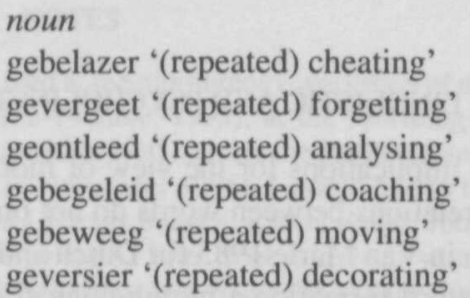

This implies that we cannot account for the gender assignment of such converted nouns in terms of 'morpheme syntax', i.e. in a purely syntagmatic approach to morphology.

A second, related generalization is that complex nouns that are created by conversion from separable complex verbs are always non-neuter, i.e. de-words (Don 1993: 156):

(34)

$$
\begin{aligned}
& \text { particle-verb } \\
& \text { aan-vang 'to begin' } \\
& \text { aan-voer 'to supply' } \\
& \text { aan-hef 'to begin' } \\
& \text { op-vang 'to support' } \\
& \text { uit-leen 'to lend' }
\end{aligned}
$$

\section{noun}

de aanvang 'beginning' de aanvoer 'supply' de aanhef 'beginning' de opvang 'support de uitleen 'lending' 
As Don points out, the gender of these nouns cannot be predicted by considering them as nominal compounds, because the right constituents do not exist as independent words: *de vang, *de voer, *de hef, *de leen. So it is the specific nature of being conversions (correlates) of prefix-verbs versus particle-verbs that must be used to predict the gender of such nouns. This way of computing the gender of a class of complex nouns is therefore another case for the role of paradigmatics in formal regularities of a morphological system.

It is also possible to give a non-paradigmatic interpretation of this regularity, however, since the particle/prefix distinction can also be encoded on these converted nouns, if we introduce labels such as 'prefix' and 'particle' for the first constituents of these complex, converted nouns. We can then refer directly to the nature of the first constituent of the nouns in computing the gender. We might also predict the gender on the basis of the differences in stress: in the prefixed nouns it is the verbal stem that has stress, whereas in the particle noun it is the particle that bears stress (Morin, pers. comm.).

What these different analyses have in common is that a formal property of complex nouns, gender, cannot be encoded as a property of one of its constituent morphemes, but has to be computed by a specific morphological rule that either refers to the properties of a paragdimatically related word, or to the morphological structure of the nominal converse. Thus, these facts underline the autonomy of morphology.

\section{LINGUISTIC AND PSYCHOLINGUISTIC IMPLICATIONS}

The linguistic implications for the view of morphology as advocated above is that paradigmatic relations between words do not only play a direct role in word formation (as shown in Van Marle 1985 for Dutch and Becker 1990, 1993 for German). In paradigmatic word formation a morphological constituent is replaced with another one, as in the Dutch word reizig-ster 'female traveler', derived from reizig-er 'traveler' by replacement of -er with -ster. Paradigmatic relations were shown to play a crucial role in purely formal aspects of morphology, such as stem allomorphy, too.

A general psycholinguistic implication of the view of morphological systems as outlined above is that the nature of the lexical relations between words in the mental lexicon is much more diversified than is often assumed. The traditional morphological question in psycholinguistics is to what extent the morphological structure of a complex word plays a role in perception and production. There seems to be a growing consensus that morphologically complex words in which the base word is recognizable both formally and as to its semantic contribution, are connected to that base word in the lexicon (Marslen-Wilson et al. 1994). However, on the basis of the arguments of paradigmatic morphology in general, and the analyses of formal regularities presented here, we conclude that this kind of lexical relation is only one among a number of possible ones, and that our notion of lexical relationship should be refined. 
The facts discussed also raise questions for models of language perception and production. For instance, we might wonder if the fact that the meaning of the adjective Amerikaans is not a compositional function of its affix and the meaning of Amerikaan negatively affects the processing of such an adjective. And does stem allomorphy of the kind discussed above, with no transparent phonological relation between the allomorphs, imply that each allomorph has its own lexical access representation, unlike what is assumed for the allomorphy in sane-sanity by MarslenWilson et al. (1994)? And is there any difference between predictable and unpredictable stem allomorphy in this respect? Note also that stem allomorphy at least adds to the complexity of the task of computing the form of a complex word. This suggests that speakers of a language with extensive stem allomorphy might exhibit a stronger preference for storage of complex words than speakers of a language without this kind of allomorphy.

The existence of such complicated patterns of formal relationships between morphologically related words also raises the question whether everything is possible, or whether there are constraints on the possible formal relationships between words. This issue has been taken up in the work of Carstairs-McCarthy (1987) that deals with constraints on inflectional paradigms. Clearly, it deserves deeper investigation in the area of word formation as well.

\section{NOTES}

1 Versions of (parts of) this paper were read at the morphology workshop of the Max Planck Institut für Psycholinguistik, Nijmegen (12-14 June, 1995), at the Morfologiedagen of the Katholieke Universiteit Leuven (21-22 September 1995), and at the 3rd Potsdamer Kolloquium zur deutschen Grammatik (Potsdam, 23-24 November 1995). I would like to thank the audiences at these meetings, and my colleagues Harald Baayen, Laurie Bauer, Johan de Caluwe, Andrew Carstairs-McCarthy, Martin Haspelmath, Eric Hoekstra, Jaap van Marle, YvesCharles Morin, Ariane van Santen, Henk Schultink and Willy Smedts for their useful comments on oral or written presentations of this material, and two anonymous referees for their written comments.

2 Similar insights can be found in Morin (1990).

3 Note that this does not imply that inflection and derivation must be separated in the sense that they do not belong to the same morphological component of the grammar. Cf. Booij $(1994,1996 \mathrm{~b})$ for a discussion of this issue.

4 Henk Schultink drew my attention to the possibility of this generalization.

5 This is an exceptional plural form although the last syllable of the stem is stressed, because it violates the subregularity that personal names in -ier such as kruiden-ier 'grocer' and portier 'porter' take the ending $-s$.

6 We do find op-zien-er besides op-zicht-er, but with a slightly different meaning, namely 'religious overseeer'.

7 It may be the case that this pattern of derivation has led to the emergence of a new suffix for native female inhabitatives, namely -se, as Koefoed \& Van Marle (1987) have argued. 


\section{REFERENCES}

Aronoff, M. 1994. Morphology by Itself. Cambridge Mass.: MIT Press.

Beard, R. 1993. "Simultaneous Dual Derivation in Word Formation'. Language 69, 716-741.

Becker, Th. 1990. Analogie und morphologische Theorie. München: Fink Verlag.

Becker, Th. 1993. "Morphologische Ersetzungsbildungen im Deutschen". Zeitschrift für Sprachwissenschaft 12, 185-217.

Berg, R. van den 1989. A Grammar of Muna. Ph. D. Diss. Rijksuniversiteit Leiden.

Booij, G.E. 1985. "Coordination Reduction in Complex Words: a Case for Prosodic Phonology". In H. van der Hulst and N. Smith (eds.) Advances in Non-linear Phonology. Dordrecht: Foris, 143-160.

Booij, G.E. 1989. "Complex Verbs and the Theory of Level Ordering". In G.E. Booij and J. van Marle (eds.) Yearbook of Morphology 1989. Dordrecht: Foris, 21-30.

Booij, G.E. 1994. "Against Split Morphology". In G.E. Booij and J. van Marle (eds.) Yearbook of Morphology 1993. Dordrecht: Kluwer, 27-50.

Booij, G.E. 1995a. The Phonology of Dutch. Oxford: Clarendon Press.

Booij, G.E. 1995b. "Review of Don (1993). In G.E. Booij and J. van Marle (eds.) Yearbook of Morphology 1994. Dordrecht: Kluwer, 297-299.

Booij, G.E. 1996a. "Lexical Phonology and the Derivational Residue". In J. Durand and B. Laks (eds.) Current Trends in Phonology. Paris: CNRS.

Booij, G.E. 1996b. "Inherent versus Contextual Inflection and the Split Morphology Hypothesis". In G.E. Booij and J. van Marle (eds.) Yearbook of Morphology 1995. Dordrecht: Kluwer, 1-16.

Booij, G.E. and A. van Santen 1995. Morfologie. De Woordstructuur van het Nederlands. Amsterdam: Amsterdam University Press.

Carstairs-McCarthy, A. 1987. Allomorphy in Inflexion. London: Croom Helm.

Dimmendaal, G. 1983. The Turkana Language. Dordrecht: Foris

Don, J. 1993. Morphological Conversion. Utrecht: LEd/OTS.

Haas, W. de, and M. Trommelen 1993. Morfologisch Handboek van het Nederlands. Den Haag: SDU Uitgeverij.

Haeringen, C.B. van 1962. "Afleidingen en samenstellingen van doen, gaan, slaan, staan en zien". In id. Neerlandica. Assen: Van Gorcum, 237-245.

Haspelmath, M. 1993. A Grammar of Lezgian. Berlin: Mouton de Gruyter.

Koefoed, G. and J. van Marle 1987. "Requisites for Reinterpretation". In W. Koopman (ed.) Explanation and Linguistic Change. Amsterdam: Benjamins, 121-150.

Lieber, R. 1981. On the Organization of the Lexicon. Bloomington Ind.: IULC [reprinted by Garland Press, New York].

Marle, J. van 1982. "Een niet-generaliserende analyse van schwa-deletie". Spektator 11, 326341.

Marle, J. van 1985. On the Paradigmatic Dimension of Morphological Creativity. Dordrecht: Foris.

Marslen-Wilson, W. et al. 1994. "Morphology and Meaning in the English Mental Lexicon". Psychological Review 101, 3-33.

Matthews, P.H. 1972. Inflectional Morphology. A Theoretical Study Based on Aspects of Latin Verb Conjugation. Cambridge: Cambridge University Press.

Morin, Y-C. 1990. "Parasitic Formation in Inflectional Morphology" in W.U. Dressler et al. (eds.) Contemporary Morphology. Berlin: Mouton de Gruyter, 197-202.

Schultink. H. 1995. "Van conversie en nog wat. Kanttekeningen bij het proefschrift van Jan Don". De Nieuwe Taalgids 88, 111-123.

Shapiro, M. 1966. "The Derivational Morphology of Russian Patrials". Lingua 16, 14-26, 113-129.

Smedts, W.A.J. 1973. "Etnica en adjectiva bij toponiemen". Naamkunde 5, 168-185. 
Smedts, W.A.J. 1974. Adjectivering en appellativering van toponiemen. Een synchronischdescriptieve studie. Leuven: Instituut voor Naamkunde (Naamkunde, bijlage LXIII).

Szymanek, B. 1985. "On Intermorphic Extensions". In E. Gussmann (ed.) Phono-Morphology. Studies in the Interaction of Phonology and Morphology. Lublin: Catholic University of Lublin, 177-192.

Toorn, M.C. van den 1982. "Tendenzen bij de beregeling van de verbindingsklank in nominale samenstellingen I". De Nieuwe Taalgids 75, 24-33.

Trommelen, M. and W. Zonneveld 1986. "Dutch Morphology: Evidence for the Right-hand Head Rule". Linguistic Inquiry 17, 147-169.

Vogel, I. 1994. "Verbs in Italian Morphology". In G.E. Booij and J. van Marle (eds.) Yearbook of Morphology 1993. Dordrecht: Kluwer, 219-254.

Zwicky, A.M. 1985. "How to Describe Inflection”. Berkeley Linguistics Society 11, 372-386.

\author{
Holland Institute of generative Linguistics \\ Vrije Universiteit, Vakgroep Taalkunde \\ De Boelelaan 1105 \\ 1081 HV Amsterdam \\ The Netherlands \\ e-mail:booij@let.vu.nl
}

